\title{
Ectopic Ventricular Rhythm by ECG Finding
}

National Cancer Institute

\section{Source}

National Cancer Institute. Ectopic Ventricular Rhythm by ECG Finding. NCI Thesaurus.

Code C71042.

An electrocardiographic finding of three or more consecutive complexes of ventricular origin. The QRS complexes are wide and have an abnormal morphology. (CDISC) 